\title{
Aspects of formation and degradation of polychlorinated dibenzo-p-dioxins and dibenzofurans
}

\author{
ZHENG Minghui ${ }^{1}$, LIU Pengyan ${ }^{2}$, BAO Zhicheng ${ }^{1}$ and XU Xiaobai' \\ 1. Research Center for Eco-Environmental Sciences, Chinese Academy of Sciences, Beïing 100085, China \\ 2. Department of Chemistry, Hebei University, Baoding 071002, China
}

Abstract The research progress on the mechanisms of formation and degradation of polychlorinated dibenzo-p-dioxins (PCDDs) and dibenzofurans (PCDFs) is reviewed. The primary sources of PCDD/Fs are chemical, thermal, photochemical and enzymatic reactions. Most of the thermal sources result in emissions into air. The studies on the photodegradation and biodegradation offer promise for destruction of PCDD/Fs in environment.

Keywords: polychlorinated dibenzo-p-dioxins, polychlorinated dibenzofurans, mechanlsm, formation, degradation.

POLYCHLORINATED dibenzo-p-dioxins (PCDDs) and dibenzofurans (PCDFs) are two series of almost planar tricyclic aromatic compounds with very similar chemical properties. Different degrees and positions of chlorination on the aromatic ring structures can occur, leading to 75 PCDD and 135 PCDF isomers in total. The most toxic isomers are 17 congeners that are fully chlorinated in the 2, 3, 7, 8-positions. A draft of four-year-long (1991-1994) US EPA reassessment of PCDD/Fs restated findings that PCDD/Fs is a probable human carcinogen. And it broke new ground in its discussion of noncancer health effects of the compounds such as disruption of the endocrine, reproductive, and immune systems ${ }^{[1]}$. Due to environmental persistence of $\mathrm{PCDD} / \mathrm{Fs}$, these classes of compounds have ubiquitous distribution. The primary exposure of humans to these lipophilic compounds is via the food chain .

Many efforts have been made at various laboratories to present formation or degradation mechanisms and derive technologies for minimization of these compounds. Although extensive investigation on PCDD/ Fs in environment has not been carried out in China, some reports concerned about a few pollution areas revealed that $\mathrm{PCDD} / \mathrm{Fs}$ released through chemical processes have resulted in serious environmental pollution in China ${ }^{[2-9]}$. It is important to investigate the characteristic of mechanisms of formation PCDD/Fs in China and explore methods of solving the problem of PCDD/Fs pollution.

\section{The natural production of PCDD/Fs}

The production of chloromethane and other organochlorine compounds, when organic material is burned, in association with the omnipresent chloride ion, led to the belief that PCDD/Fs could form during combustion processes in nature. Laboratory studies have revealed that PCDD/Fs form in parts-per-billion amounts during the combustion of wood. It is estimated that about $59 \mathrm{~kg}$ of PCDDs is produced in Canadian forest fire annually ${ }^{[10,11]}$. Thomas reported that about $0.2 \mathrm{~kg}$ toxicity equivalent (TEQ) is produced annually in the U.S. forest fires ${ }^{[12 j}$. Because there are 20000 forest fires annually worldwide that burn 43 000 square kilometer, it is logical to assume that PCDD/Fs have been present in the environment for many centuries $^{[13]}$.

Another milestone observation is the enzymatic conversion of chlorophenols into $\mathrm{PCDD} / \mathrm{Fs}$ in the parts-per-million range by horse-radish peroxidase enzyme (HRP). The equation is given below ${ }^{[14]}$.

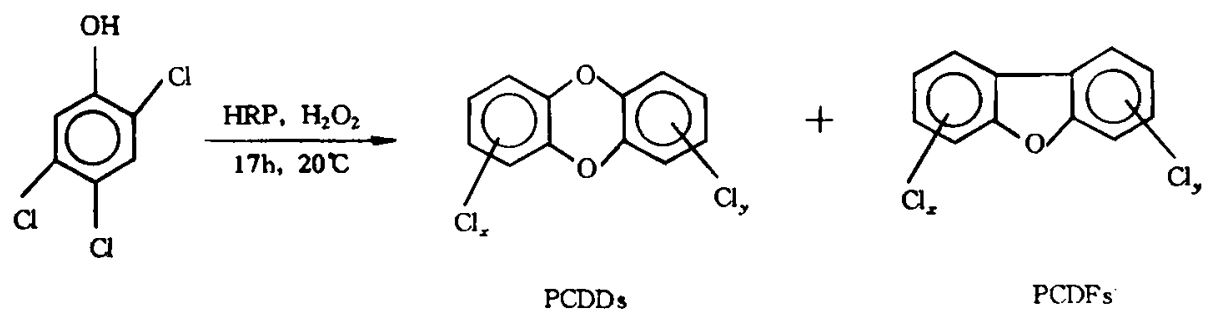


This extraordinary revelation opens the door to the possibility that a source of environmental PCDD/Fs may be their completely natural formation from (natural) chlorophenols by soil and water microbes. Recent evidence shows that these reactions also occur under true environmental conditions in sewage sludge and peat $\operatorname{bogs}^{[15,16]}$.

The formation of PCDDs from pentachlorophenol (PCP) in wood matrix and water by photolytic condensation under natural sunlight was demonstrated by Lamparski et al ${ }^{[17,18]}$. The equation is shown below .<smiles>Oc1c(Cl)c(Cl)c(Cl)c(Cl)c1Cl</smiles>

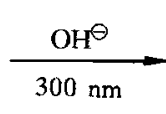<smiles>Clc1c(Cl)c(Cl)c2c(c1Cl)Oc1c(Cl)c(Cl)c(Cl)c(Cl)c1O2</smiles>

Kjeller et al. analyzed sediment core from the northwestern part of the Baltic Proper ${ }^{[19]}$ and herbage collected between 1861 and 1993 from a well characterized rural site in southeast England ${ }^{[20]}$. The results showed that PCDD/Fs concentration peaked in the 1960s and 1970s and have declined since then. Fig. 1 shows the levels of $\mathrm{PCDD} / \mathrm{Fs}$ in a sediment core from Baltic Proper. The US EPA' s draft of dioxin risk reassessment stated that ancient human tissue sampling shows much lower PCDD/Fs levels than found today. Studies of sediment cores in the lakes near industrial center of the U.S. have shown that PCDD/Fs were quite low till about 1920 . These studies show tal PCDD.

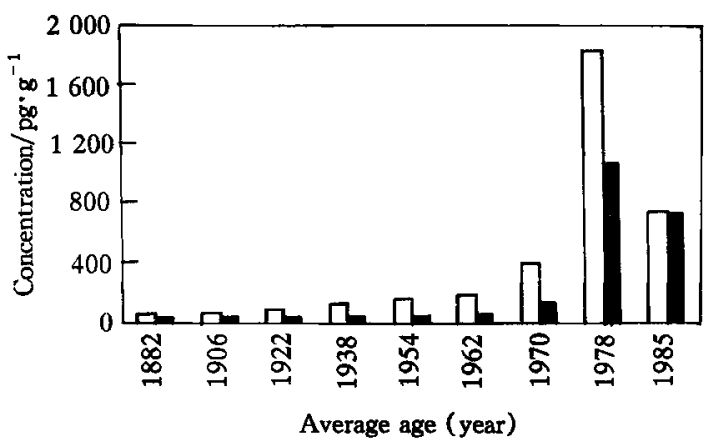
increases in PCDD/Fs concentrations beginning in the $1920 \mathrm{~s}$ and continuing till about $1970^{[1]}$. On these bases, it appears that the presence of PCDD/Fs in the environment occurs primarily as a result of anthropogenic practices.

\section{Anthropogenic emissions of PCDD/Fs}

PCDD/Fs are not produced intentionally, but are released into the environment in ultratrace amounts from various combustion processes and as a result of their occurrence as unwanted byproducts in various chlorinated chemical formulations.

( i ) Chemical processes. Many chemical reactions may result in the contamination of pesticides and technical products including chlorophenols, chlorophenoxy herbicides and polychlorinated biphenyls (PCBs). The production and use of these chemicals are nowadays banned or strictly regulated in most countries, but during the $1960 \mathrm{~s}$ and $1970 \mathrm{~s}$ these products were widely used and hence became a major source of PCDD/Fs contamination for the environment.

Chlorophenol has been used as preservative and biocide for many years. Although there were no accurate annual production figures for individual chlorophenols pesticides, the total production of all pesticides of this type was estimated to be $1.5 \times 10^{8} \mathrm{~kg}$ in 1980 . Figures on PCP are available for the U. S. between 1972 and 1977 . Average of annual production during this period was about $2 \times 10^{7} \mathrm{~kg}$. The $\mathrm{PCDD} / \mathrm{Fs}$ content of commercial PCP mixtures was measured to be in the range of $205-1070 \mathrm{ppm}$. Using these figures and the U.S. production estimates, it can be calculated that $4 \times 10^{3}-21 \times 10^{3} \mathrm{~kg}$ of PCDD/ Fs was produced annually in the U.S. during PCP manufacture ${ }^{[21]}$.

Being contaminants of technical PCP and Na-PCP, it is estimated that the environment emission of 
PCDD/Fs was about $240 \mathrm{~kg}$ PCDD/Fs or $1 \mathrm{~kg}$ TEQ annually from the $1970 \mathrm{~s}$ to the $1980 \mathrm{~s}$ in China. NaPCP has been spread since the 1960s to control the spreading of snailborne schistosomiasis in the south of China. The analysis results of samples from these areas show that the levels of PCDD/Fs are significantly high $^{[7,8]}$. Bao reported findings about $10 \%$ of $\mathrm{PCDD} / \mathrm{Fs}$ in the waste from reaction still for production of PCP by pyrolysis of hexachlorocyclohexane ( $\mathrm{HCH})$. It can be calculated that $1.5 \times 10^{4} \mathrm{~kg} \mathrm{PCDD} / \mathrm{Fs}$ or 90 $\mathrm{kg}$ TEQ is produced annually at the factory from 1990 to 1993.

Zheng et al. studied the mechanism of formation of PCDD/Fs from the pyrolysis of HCH. It was revealed that $\mathrm{FeCl}_{3}$ plays an important part in formation of $\mathrm{PCDD} / \mathrm{Fs}$ from the pyrolysis of $\mathrm{HCH}$. The pattern of PCDD/Fs from products of the laboratory experiments is similar to the waste of the chemical factory .

Maximum production of 2,4,5-T was reached between 1960 and 1970 , with the total of $48.2 \times 10^{6}$ $\mathrm{kg}$ produced in the world. The concentrations of $2,3,7,8-\mathrm{TCDD}$ in $2,4,5-\mathrm{T}$ have been determined in several laboratories. If we assume that the upper $2,3,7,8$-TCDD concentration limit was 100 ppm and the lower limit was $0.1 \mathrm{ppm}$, then the maximum amount of 2, 3, 7, 8-TCDD produced from 1960 to 1970 was about $4.8 \times 10^{3} \mathrm{~kg}$. More than 11 million gallons of Agent Orange $(1: 1 w / w 2,4-\mathrm{D}$ and 2, 4, 5-T) were sprayed on jungles of Vietnam. Many people still suffered greatly while exposed to PCDD/Fs there.

PCBs production increased greatly at the end of the sixties, but by the end of the seventies, production decreased sharply due to environment concerns. The U. S. produced $58.9 \times 10^{6} \mathrm{~kg}$ commercial PCB mixture, Aroclors 1248,1254 and 1260 , from 1968-1970, that was about half of the world total. It can be estimated that a total of $84-94 \mathrm{~kg}$ of PCDFs was produced from production of PCBs in the U. S. during this period ${ }^{[21]}$.

The Chinese commercial PCBs, known as $\mathrm{PCB}_{3}$ and $\mathrm{PCB}_{5}$, were found to contain PCDD/Fs at about 217-417 ng TEQ/g. Approximately $10 \times 10^{6} \mathrm{~kg}$ commercial PCBs was produced from 1965 to 1974 in China. Most of these PCBs products were used as dielectric fluid in electronic capacitors, and a small part of which was used as additives in paints. The electronic capacitors containing PCBs have been considered as solid wastes since the $1980 \mathrm{~s}$.

(ii ) Pulp bleaching. During Dioxin' 86 in Japan Rappe reported findings of PCDD/Fs from samples of crab hepatopancreas and sediments collected outside a pulp mill in Sweden. The levels of 2, 3, 7 , 8-TCDD and 2, 3, 7, 8-TCDF were at least ten times higher in the samples collected outside the mill than in the background samples. Changing bleaching processes and wastewater treatment enabled the industry to reduce the amount of PCDD/Fs by more than $90 \%$ between 1988 and 1992 in the U.S.A. A $98 \%$ decrease in PCDD/Fs originating from bleaching operations over the period from 1988 to 1993 for the entire Canadian chemical pulping sector was observed ${ }^{[25]}$.

Non-wood plant fibers in paper making nowadays in China are dominant. Bleaching of non-wood plant fibers in China usually requires only a single step of hypochlorite bleaching process. The levels of PCDD/ Fs in the bleached pulp from five pulp mills are about $30 \mathrm{pg}$ TEQ/g dry pulp ${ }^{[6]}$.

( iii ) Metal processing. It was reported that PCDD/Fs could be identified in dust from a steel mill in Sweden at levels of $800 \mathrm{pg} \mathrm{TEQ/g}$ dust in 1986. A study in a pilot plant reported collection of smoke containing $110 \mathrm{ng} \mathrm{TEQ} / \mathrm{m}^{3}$, where scrap metal was melted and recycled using batchwise charging. The Swedish EPA considers the production of iron and steel to be the major source of PCDD/Fs in Sweden ${ }^{[15]}$. It is estimated that 50-150 g TEQ PCDD/Fs was produced annually during metal processing in the $\mathrm{U}$. $\mathrm{S} .{ }^{[26]}$. PCDD/Fs are emitted by the burning of scrap metal such as copper cable coated with PVC plastic insulation. In fly ash from a copper wire and aluminum scrap recovery facility, PCDD/F's concentrations are $50-460 \mathrm{ppm}^{[27]}$.

(iv) Combustion processes. The emissions of $\mathrm{PCDD} / \mathrm{Fs}$ from incineration processes were first observed by Olie et al. ${ }^{[28]}$. Since then, numerous measurements have been performed in a variety of combustion sources, and trace quantities of PCDD/Fs emissions have been found in most combustion sources. Municipal solid waste incinerators (MSWI) have been suggested as most serious PCDD/Fs emission sources judging from the high $\mathrm{PCDD} / \mathrm{Fs}$ concentrations in flue gas and flue gas discharged from incinera- 
tors, and therefore, have been the subject of major research efforts to reduce PCDD/Fs pollution. The $U$. S. EPA's dioxin reassessment showed that waste combustion accounted for about $95 \%$ of all the known PCDD/Fs emission. Medical and municipal waste combustion dominates combustion sources. The U.S. $\mathrm{PCDD} / \mathrm{Fs}$ emissions from combustion sources are shown in table $1^{\left[12^{\circ}\right.}$.

A better understanding of the mechanism of PCDD/Fs formation provides a better guidance for devising technical control measures and improving the performance of practical combustion equipment in order to reduce PCDD/Fs emissions. Many incinerators reduce the emission of PCDD/Fs to a level below $0.1 \mathrm{ng}$ $\mathrm{TEQ} / \mathrm{m}^{3}$ which is the guideline in many European countries ${ }^{[15]}$.

Table 1 The USA annual PCDD/Fs emissions from combustion sources ( $\mathrm{g}$ TF,Q/year)

\begin{tabular}{cccccc}
\hline $\begin{array}{c}\text { Medical waste } \\
\text { incineration }\end{array}$ & $\begin{array}{c}\text { Municipal waste } \\
\text { incineration }\end{array}$ & $\begin{array}{c}\text { Petroleum } \\
\text { combustion }\end{array}$ & $\begin{array}{c}\text { Industrial wood } \\
\text { burning }\end{array}$ & $\begin{array}{c}\text { Residential } \\
\text { wood buming }\end{array}$ & Coal combustion \\
\hline 5000 & 2000 & 90 & 150 & 40 & 10 \\
\hline
\end{tabular}

In spite of 20-year research and obtained insights in the reactivity of fly ash towards PCDD/Fs formation, the mechanism of formation of these compounds remains unclear ${ }^{[30]}$. Recent discussions of the possible mechanisms of $\mathrm{PCDD} / \mathrm{Fs}_{\mathrm{s}}$ formation have focused on two hypotheses: i ) Dickson et al. have proposed that $\mathrm{PCDD} / \mathrm{Fs}$ are formed from chloroaromatic precursors such as chlorophenols ${ }^{[31-33]}$ and chlorobenzenes ${ }^{[34]}$ by reactions which have been shown to occur by heterogeneous catalysis on the surface of fly ash particles at $250-400^{\circ} \mathrm{C}$. These products could be formed by Ullman-type surface reaction. The precursors might be already present in the fuel, or they could be formed in the higher temperature postcombustion zone by multistep reactions, including aromatization of aliphatic cornpounds and subsequent chlorination by molecular chlorine ${ }^{[35]}$. A source of $\mathrm{Cl}$ for the organic precursors may be provided through the metal catalyzed Deacon reaction:

$$
2 \mathrm{HCl}+\frac{1}{2} \mathrm{O}_{2} \rightarrow \mathrm{H}_{2} \mathrm{O}+\mathrm{Cl}_{2}
$$

Chlorophenols and chlorobenzenes can also be produced from heterogeneous combustion reactions of $\mathrm{C}_{2}$ aliphatics $^{[36]}$. if ) Stieglitz et al. have suggested a de novo synthesis of PCDD/Fs from active carbon particulates by gas-solid and solid-solid reactions with air, moisture and inorganic chlorides, catalyzed by $\mathrm{Cu}$ (II ) ions ${ }^{[37,38]}$.

Dickson et al. demonstrated that PCDDs are formed from the model precursor compound PCP much faster than from reactions of particulate carbon in the heterogenous phase under identical conditions. In the postcombustion and heat exchanger sections of an incinerator fast reactions of chlorophenols and chlorobenzenes precursors leading to $\mathrm{PCDD} / \mathrm{Fs}$ formation are expected to predominate. In pollution control equipment slower processes such as de novo synthesis from particulate carbon may contribute to the levels and distribution of PCDD/Fs congeners and other chlorinated organic compounds in incinerator emission ${ }^{\text {[35] }}$.

De novo synthesis led to the proposal of particulate carbon_- present in all fly ashes after extraction as most likely precursor. If true, questions then arise: what is the nature of this carbon, and how is it mobilized from the solid carbon matrix to form aromatic moieties? The previous work by Stromberg $e t$ al. suggested that $\mathrm{CO}_{2}$ could act as a precursor to chlorobenzenes under proper conditions via a FisherTropsch type mechanism ${ }^{[40,41]}$. However experiments with ${ }^{13} \mathrm{C}$-labeled $\mathrm{CO}$ and $\mathrm{CO}_{2}$ reacting with fly ash showed that neither is an effective precursor to $\mathrm{PCDD} / \mathrm{Fs}^{[42 j}$.

Froese et al. showed that heterogeneous combustion reactions of acetylene produce chlorobenzenes, chlorophenols and $\mathrm{PCDD} / \mathrm{Fs}^{-39}$ ]. This experiment hints that there is relationship between the two postulations ${ }^{[39]}$. A simplified schematic of conceivable de novo and precursor PCDD/Fs formation pathway is summarized in figure 2 . 


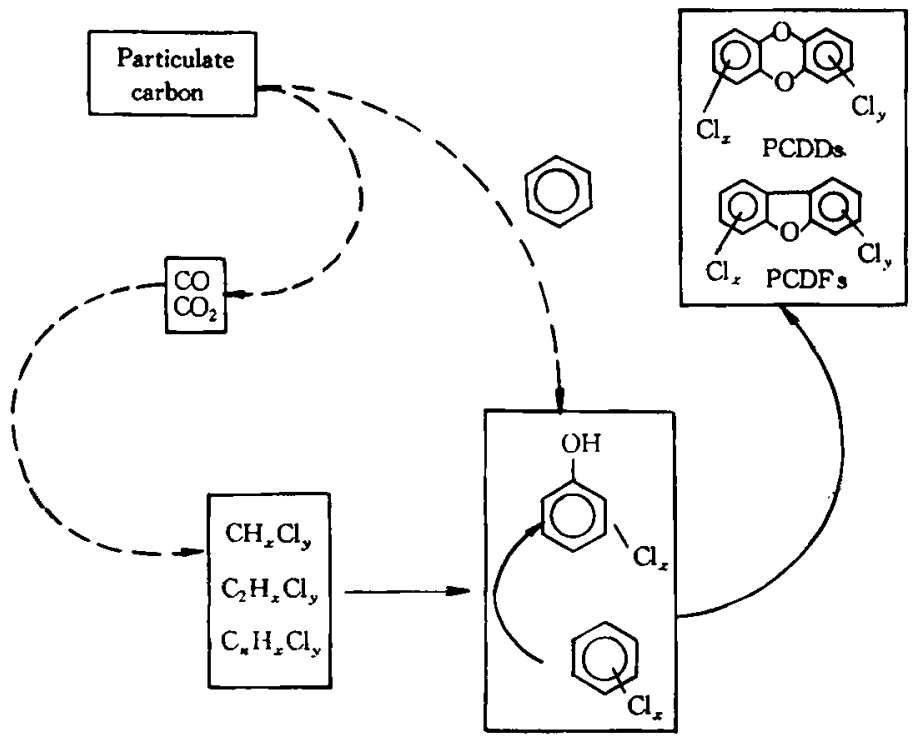

Fig. 2. Potential PCDD/Fs formation routes in incineration.

\section{$3 \mathrm{PCDD} / \mathrm{Fs}$ emissions in some countries}

Table 2 shows PCDD/Fs emissions estimates from the known sources.

Table $2 \mathrm{PCDD} /$ Fs emissions in some countries

\begin{tabular}{ccccc}
\hline Country & Level g TEQ & Emission source & Year \\
\hline Germany & $1619-12419$ & all sources into the air & 1989 \\
UK & $560-1100$ & all sources into the air & 1995 \\
The Netherlands & 962 & all sources into the air & 1989 \\
Sweden & $100-200$ & all sources into the air & 1991 \\
USA & 13600 & known sources & 1993 \\
\hline
\end{tabular}

These figures are based on limited data and must be considered as very rough estimates.

\section{Studies on the degradation of PCDD/Fs}

( i ) Photodegradation of PCDD/Fs. i ) Photolysis of PCDD/Fs in solvents. It is known that $\mathrm{PCDD} / \mathrm{Fs}$ decompose in organic solution if they are irradiated by UV-light of $250-315 \mathrm{~nm}$. Grosby et al . found that $2,3,7,8$-TCDD undergoes rapid photolysis in methanol under UV light ${ }^{[4]}$. Buser demonstrated that dechlorination of higher chlorinated PCDD/Fs to lower chlorinated ones appears to be the major reaction pathway. The products of OCDD photodegradation suggested a preferential loss of the chlorine atoms in lateral $(2-, 3-, 7-, 8-)$ positions on the dibenzo-p-dioxin ring ${ }^{[44}$. Experiments showed that the rate of photolysis of OCDD is greatly affected by the surrounding solvent medium. The measured first order rate indicates that photolysis occurs more rapidly in solvents that are good $\mathrm{H}$ donors ${ }^{[45]}$. Zheng et al. reported that photolysis of PCDDs in carbon tetrachloride with UV light produces the corresponding chlorobenzenes. $\mathrm{C}-\mathrm{O}$ bond rather than $\mathrm{C}-\mathrm{Cl}$ bond cleavage is found to be a major pathway for photodegradation of PCDDs ${ }^{[46]}$. Photolysis of PCDDs in chlorform by a $300 \mathrm{~W}$ medium pressure mercury Vapor lamp showed that half-lives of the compounds are less than $5 \min ^{[47]}$.

The mechanism of photolytic degradation of $\mathrm{PCDD} / \mathrm{Fs}$ in water is not clear. The photolysis of 2,3 , 7, 8-TCDD appears to be considerably less efficient in water than in hexane at $313 \mathrm{~nm}^{[48]}$. However, photolysis rates of 2, 7-DCDF, 2,3,7,8-TCDF and 1,2,7,8-TCDF in aqueous solution irradiated at $300 \mathrm{~nm}$ are 4-15 times faster than in organic solutions, and in the cases of $2,7-D C D F$ and $1,2,7,8-$ TCDF, 20 times faster than in $60 \%$ acetonitrile/water. Dechlorination may be a major process in the pho- 
todecomposition of higher chlorinated PCDFs in hydrocarbon solvents but not in water ${ }^{[49]}$. Several studies have shown that the photolysis rates of both PCDDs and PCDFs may be significantly enhanced in natural water, a fact usually attributed to the presence of naturally occurring sensitizers ${ }^{[50]}$. Although the identity of the sensitizers is unknown, dissolved fulvic and humic acids and proteins have been shown to sensitize the photodegradation of organic contaminants in aqueous solutions.

ii ) Photolysis of PCDD/Fs at the surface of solids. Strong public concern posed by PCDD/Fs has spurred research efforts to develop treatments to eliminate these hazards. Several successful techniques that have been reported for contaminated soil sites involve difficult and expensive procedures. The needs for practical, lower cost techniques still exist. The facts that photolysis of OCDD on soil by UV irradiation produces 2, 3, 7, 8-TCDD suggested a preferential loss of the chlorine atoms in ortho (1-, 4-, 6-, 9-) positions ${ }^{[51,52]}$. Many studies were made to estimate the theoretical maximum rate for soil decontamination. Mathematic analysis of these studies showed that the average decontamination rate is $3.3 \mathrm{ng}$ TCDD/ $\mathrm{h} \mathrm{cm}^{2[53]}$. Since photolysis can occur only in a shallow zone at the surface of soil in the depth of $0.06-$ $0.13 \mathrm{~mm}$, PCDD/Fs molecules must first be brought into solution and then transported to the surface by solvent related processes. Substantial photodegradation $(60 \%-85 \%)$ of TCDD throughout $6 \mathrm{~cm}$ deep soil column was found after $60 \mathrm{~d}$ sunlight exposure ${ }^{[54]}$. Yan et al. reported the effect of cocontaminants in soil on the photodegradation of PCDDs. The cocontaminants could be quenchers or sensitizers and change the efficiency of phototransformation ${ }^{[55,56]}$.

Hosoya et al. used octadecylsilylated silica gel $\left(\mathrm{C}_{18}\right)$ as a reaction medium for the photolysis of 2 , 3,7,8-TCDD in 10\% 2-propanol/water. The compound decomposed completely in $5 \mathrm{~min}$ after being exposed to a $450 \mathrm{~W} \mathrm{UV}$ lamp. It is demonstrated that complete $\mathrm{C}_{18}$ trapping with continuous photodecomposition of TCDD contained in an aqueous alcohol waste is possible ${ }^{[55]}$. Schuler et al. investigated the photodegradation of PCDD/Fs dissolved in cuticular wax from laurel cherry leaves. Application of the results to an exiting model of atomspheric deposition of aerial contaminants demonstrated that photodegradation is an important process in the fate of $\mathrm{PCDD} / \mathrm{Fs}$ on vegetation and in the use of vegetation as a tool for air monitoring of $\mathrm{PCDD} / \mathrm{Fs}^{[57]}$.

iii ) Advanced oxidation processes. Advanced oxidation processes have already found a widespread application in the treatment of industrial wastewater, ground water and landfill leachate. Zhang et al. used $\mathrm{TiO}_{2}$ to catalyze the photolysis of PCDDs in an aqueous system. The results showed that PCDDs tested in the experiment were destroyed by $84 \%-91 \%$ within $4 h^{[58]}$. The quantum yield of OCDD photodegradation is increased about fourfold when $0.3 \% \mathrm{H}_{2} \mathrm{O}_{2}$ has been incorporated into the solution ${ }^{[56]}$. Vollmuth $e t$ al. expected a better way to destroy PCDD/Fs contaminants in seepage water by UV/ozone treatment, but there is still a long way to go ${ }^{[59]}$. Sommer et al. investigate the photochemical decomposition of PCDD/Fs on fly ash particles from municipal solid waste with medium and low pressure mercury lamps in an oxygen/ ozon atmosphere. The maximum value of the degradation rates is about $70 \%{ }^{[60]}$.

(ii ) Biodegradation of PCDD/Fs. Bioremediation strategies for PCDD/Fs contaminated environments would be a highly desirable approach, as it may be considerably less costly than physical-chemical processes, and as it can be used in situ. However very few bacterial or fungal species are known to degrade PCDD/Fs. The half-life of TCDD in soil in the absence of UV light is approximately 10 years, indicating the general lack of alternative degradation pathway. Du et al. demonstrated that 8 bacteria strains screened from contaminated soil could degrade 2-chlorinated dibenzo-p-dioxin well, 1 of the 8 bacteria strains could degrade $2,3,7-\mathrm{T}_{3} \mathrm{CDD}^{[62]}$. The fate of $\mathrm{PCDD} / \mathrm{Fs}$ was studied in anaerobic microcosms, using PCB contaminated sediments, and creosote contaminated aquifer sediments. The PCDD/Fs concentrations in active microcosms were shown to decrease at higher rates than in chemical and biological controls. Peri-dechlorinated was found under anaerobic methanogenic conditions ${ }^{[63]}$. Disse compared PCDD/Fs concentrations after aerobic and anaerobic digestion of sewage sludge. The aerobic digestion occurred in ventilated batch reactors leading to a significant degradation of $\mathrm{PCDD} / \mathrm{Fs}_{\mathrm{s}}{ }^{[64]}$.

(iii) Other methods for the destruction of $\mathrm{PCDD} / \mathrm{Fs}$. Hilarides et al. showed that gamma irradia- 
tion is both a technically and economically feasible method to degrade PCDD/Fs. Approximately $99 \%$ degradation of $2,3,7,8$-TCDD on a model soil was achieved using gamma radiation at a dose of 800 $\mathrm{kGy}^{[65]}$. Oku used alkali-metal hydroxide in 1,3-dimethyl-2-imidazolidinone to destroy PCDD/Fs. Highly efficient destruction $(>99.99 \%)$ of PCDD/Fs was achieved ${ }^{[66]}$.

Acknowledgement This work was supported by the Chinese Academy of Sciences and National Natural Science Foundation of China (Grant No. 29707003).

\section{References}

1 ES\&T Editors, Dioxin risk, Environ. Sci. Technol., 1995, 29: 4A.

2 Bao, Z. C., Wang, K. O., Kang, J. X. et al., Analysis of polychlorinated dibenzo-p-dioxins and polychlorinated dibenzofuans in pentachlorophenol and sodium pentachlorophenate, Environ. Chem. (in Chinese), 1995., 14: 317.

3 Bao, Z. C., Wang, K. O., Kang, J. X. et al. , Analysis of 2, 3, 7, 8-substituted PCDDs and PCDFs in thermolysis waste of $\mathrm{HCH}$, Environ. Chem. (in Chinese), 1994, 13: 309.

4 Ding, X. L., Bao, Z. C., Zhang, Z. et al., Analysis of PCDDs and PCDFs in Chinese polychlorinated biphenyls, Environ. Chem. (in Chinese), 1990, 9(6): 39 .

$5 \mathrm{Li}$, L. J., Jiang K. , Determination of toxic equivalents of PCDD/Fs in two Chinese commercial PCBs by ${ }^{13} \mathrm{C}$ isotope dilution method, Acta Scientiae Circumstantiae (in Chinese), 1995, 15: 433.

6 Zheng, M. H. , Bao, Z. C., Wang, K. O. et al., Levels of PCDDs and PCDFs in the bleached pulp from Chinese pulp and paper industry, Bull. Environ. Contam. Toxicol., 1997, 59: 90.

7 Jiang, K., Li, L. J., Chen, Y. D. et al., Determination of PCDD/Fs from Chinese schistosomiasis areas and discussion of its significance for eco-environment, Chinese Sci. Bull., 1995, 40: 846.

8 Zheng, M. H., Bao, Z. C., Wang, K. O. et al., Polychlorinated dibenzo-p-dioxins and dibenzofurans in lake sediments from Chinese schistosomiasis areas, Bull. Environ. Contam. \& Toxicol. , 1997, 59: 653.

$9 \mathrm{Wu}, \mathrm{W}$. Z. , Shramm, K. -W., Henklmann, B. et al. , PCDD/Fs, PCBs, HCHs and HCB in sediments and soils of Ya-Er Lake area in China: Results on residual levels and correlation to the organic carbon and the particle size, Chemosphere, 1997, $34: 191$.

10 Nestrick, T. J., Lamparski, L. L., Isomer-specific determination of ehlorinated dioxins for assessment of formation and potential environmental emission for wood combustion, Anal. Chem., 1982, 54: 2292.

11 Sheffield, A., Sources and releases of PCDD's and PCDF's to the Canadian environment, Chemosphere, $1985,14: 811$.

12 Thomas, V. M. , Spiro, T. G., The U. S. dioxin inventory: Are there missing sources? Environ. Sci. Technol., 1996, 30: $82 A$.

13 Gribble, G. W., The natural production of chlorinated compounds, Environ. Sci. Technol., 1994, 28: 310A

14 Svenson, A., Kjeller, I_O., Rappe, C., Enzyme-mediated formation of 2, 3, 7, 8-tetrachlorinated dibenzodioxins and dibenzofurans, Environ. Sci. Technol., 1989, 23: 900.

15 Rappe, C., Dioxin patterns and source identification, Fresenius J. Anal. Chem., 1994, 348: 63.

16 Silk, P. J., Lonergan, G. C., Arsenault, T. L. et al., Evidence of natural organochlorine formation in peat bogs, Chemosphere, 1997, 35: 2865 .

17 Lamparski, L. L., Stehl, R. H., Photolysis of pentachlorophenol-treated wood: Chlorinated dibenzo-dioxin formation, Environ. Sci. Technol., 1980, 14: 196

18 Vollmuth, S., Zaje, A., Niessner, R., Formation of polychlorinated dibenzo-p-dioxins and polychlorinated dibenzofurans during the photolysis of pentachlorophenol-containing water, Environ. Sci. Technol., 1994, $28: 1145$.

19 Kjeller, L-O., Rappe, C. , Time trends in levels, patterns and profiles for polychlorinated dibenzo-p-dioxins, dibenzofurans, and biphenyls in a sediment core from the Baltic Proper, Environ. Sci. Technol. , 1995, 29: 346.

20 Kjeller, L-O., Jones, K. C. , Johnston, A. E. et al., Evidence for a decline in atmospheric emission of PCDD/Fs in the U. K, Environ. Sci. Technol., 1996, 30: 1398.

21 Hutzinger, O., Gerg, M. V. D., Olie, K. et al., Dioxins and furans in the environment: evaluating toxicological risk from different sources by multicriteria analysis, in Dioxins in the Environment (eds. Kamrin, M. A., Rodgers, P. W.), NY and London: Hemisphere Publishing Co., 1985, 9.

22 Zheng, M. H., Bao, Z. C., Wang, K. O. et al., Fomation of polychlorinated dibenzo-p-dioxins and dibenzofurans by heating hexachlorocyclohexane in the presence of $\mathrm{FeCl}_{3}$, Environ. Chem. (in Chinese), 1995, 14: 179

23 Zheng, M. H. , Bao, Z. C., Xu, X. B. et al., Formation of PCDD/Fs from the pyrolysis of HCH in the presence of iron oxide, Chemosphere, 1996, 32: 595.

24 EHP Editors, Agent orange down under, Environ. Health Perspectives, 1995, 103: 222.

25 Zheng, M. H., Bao, Z. C., Xu, X. B. et al., Discussion on the formation of polychlorinated debenzo-p-dioxin and dibenzofurans in the bleaching of pulp, China Pulp \& Paper, 1996, 15(3): 48

26 Hanson, D., C\&EN, 1994, 30:13.

27 Harnly, M., Stephens, R., Mclaughlin, C. et al., Polychlorinated dibenzo-p-dioxin and dibenzofuran contamination metal re- 
covery facilities, open bum sites, and a railroad car incineration facility, Environ. Sci. Technol., 1995, $29: 677$

28 Olie, K., Vermeulen, P., Hutzinger, O., Chlorodibenzo-p-dioxins and chlorodibenzofurans are trace components of fly ash and flue gas of some of municipal incinerators in Netherland, Chemosphere, 1977,6: 455.

29 EPA, Environmental News, Dallas: USEPA, Sept. 13, 1994

30 Lujjk, R., Formation of polyhalogenated dibenzo-p-dioxins and dibenzofurans during thermal degradation processes, Universiteit van Amsterdam, 1993.

31 Born, J. G. P., Louw, R., Mulder, P., Fly ash mediated (oxy) chlorination of phenol and its role in PCDD/F formation, Chemosphere, 1993, 26: 2087.

32 Milligan, M. S., Altwicker, E. R., Chlorophenol reaction on fly ush. 1. Adsorption/desorption equilibria and conversion to polychlorinated dibenzo-p-dioxins, Environ. Sci. Technol., 1996, 30: 225.

33 Cains, P. W., Mecausland, L. J., Fernandes, A. R. et al., Polychlorinated dibenzo-p-dioxins and dibenzofurans formation in incineration: Effects of fly ash and carbon source, Environ. Sci. Technol., 1997, $31: 776$.

34 Sommeling, P. M., Mulder, P., Louw, R., Formation of PCDFs during chlorination and oxidation of chlomobenzene in chlorine/oxygen mixture anound $340^{\circ} \mathrm{C}$, Chemosphere, 1994, 29: 2015.

35 Dickson, L. C., Lenoir, D., Hutzinger, O., Quantitative comparison of de novo and precursor formation of polychlorinated dibenzo-p-dioxins under simulated municipal solid waste incineration postcombustion conditions, Enorion. Sci. Technol., 1992, 26: 1822 .

36 Froese, K. L., Hutzinger, O., Mechanisms of formation of polychlorinated benzenes and phenols by heterogeneous reactions of $C_{2}$ aliphatics, Environ. Sci. Technol., 1997, 31:542.

37 Stieglitz, L., Zwick, G., Beck, J. et al., On the de nowo synthesis of PCDD/PCDF on fly ash of municipal waste incinerators, Chemosphere, 1989, 18: 1219 .

38 Luijk, R. . Akkerman, D. M., Slot, P. et al., Mechanism of formation of polychlorinated dibenzo-p-dioxins and dibenzofurans in the catalyzed combustion of carbon, Environ. Sci., Technol., 1994, 28: 312.

39 Froese, K. I., Hutzinger, 0., Polychlorinated benzene, phenol, dibenzo-p-dioxin, and dibenzofuran in hetemgeneous combustion reactions of acetylene, Environ. Sci. Technol., 1996, 30: 998.

40 Stromberg, B., Carbon dioxide-A precursor for dioxins? Chemosphere, 1991, 23: 1515.

41 Milligan, M. S., Altwicker, E. R., The relationship between de nowo synthesis of polychlorinated dibenzo-p-dioxins and dibenzofurans and low-temperature carbon gasification in fly ash, Environ. Sci. Technol., 1993, $27: 1595$.

42 Milligan, M. S., Altwicker, E. R., Mechanistic aspects of the de nowo synthesis of polychlorinated dibenzo-p-dioxins and furans in fly ash from experiments using isotopically labeled reagents, Environ. Sci. Technol , , 1995, $29: 1353$.

43 Crosby, D. G., Woolson, A. S., Photodecomposition of chlorinated dibenzo-p-dioxins, Science, 1971, $173: 748$.

44 Buser, H. R., Preparation of qualitative standard mixtures of polychlorinated dibenzo-p-dioxins and dibenzofurans by ultraviolet and $\gamma$-irradiation of the octachloro compounds, J. Chromatogr., 1976, 129: 303.

45 Hung, H.-S., Ingram, L. L., Effect of solvents on the photodegradation rates of octachlorodibenzo-p-dioxin, Bull. Environ. Toxicol. , 1990, 44: 380 .

46 Zheng, M. H., Bao, Z. C., Xu, X. B. et al., Mechanism of photodegradation of polychlorinated dibenzo-p-dioxins in carbon tetrachloride, Chemosphere, 1996, 32: 603 .

47 Bao, Z. C., Zheng, M. H., Wang, K. O., Ultraviolet photolysis of polychlorinated dibenzo-p-dioxins in chloroform, Environ. Chem. (in Chinese), 1995, 14: 190 .

48 Friesen, K. J., Mulr, D. C. G., Webster, G. R. B., Evidence of Sensitized photolysis of polychlorinated dibenzo-p-dioxins in nature water under sunlight conditions, Environ. Sci. Technol., 1990, 24: 1739.

49 Dung, M. H. , O' Keef, P. W. , Comparative rates of photolysis of polychlorinated dibenzofurans in organic solvents and in aqueous solutions, Environ. Sci. Technol., 1994, $28: 549$.

so Friesen, K. J., Foga, M. M., Loewen, M. D., Aquatic photodegradation of polychlorinated dibenzofurans: Rates and photoproduct analysis, Environ. Sci. Technol., 1996, 30: 2504.

51 Miller, G. C., Hebert, V. R., Photolysis of octachlorodibenzo-p-dioxin on soil: production of 2, 3, 7, 8-TCDD, Chemosphere, $1989,18: 1265$.

52 Zhang, Z. J., Bao, Z. C., Zheng, M. H. et al., The UV photodegradation of polychlorinated dibenzo-p-dioxins on the surface of soil, Environ. Chem. (in Chinese), 1996, 15: 541 .

53 Dougherty, E. J., Mcpeters, A. L., Overcash, M. R., Kinetics of photodegradation of 2, 3, 7, 8-tetrachlorodibenzo-pdioxin: theoretical maximum rate of soil decontamination, Chemosphere, 1991, 23 : 589.

54 Mcpeters, A. L., Overcash, M. R., Demonstration of photodegradation by sunlight of 2, 3, 7, 8-tetrachlorodibenzo-p-dioxin in $6 \mathrm{~cm}$ soil columns, Environ. Sci. Technol., 1993, 27: 1221 .

55 Hosoya, K., Kimata, K., Fukunishi, K. et al., Photodecomposition of 1, 2, 3, 4-TCDD and 2, 3, 7, 8-tetrachlorodibenzop-dioxin (TCDD) in water-alcohol media on a soil support, Chemosphere, 1995, $31: 3687$.

56 Yan, Q., Kappila, S., Sivils, L. D. et al., Effect of sensitizers and inhibeitors on phototransformation of polychlorinated dibenzo-p-dioxins (PCDDs), Chemosphere, 1995, 31: 3627.

57 Schuler, F., Schmid, P., Schlatter, Ch., Photodegradation of polychlorrinated dibenzo-p-dioxins and dibenzofurans in cuticular waxes of Laurel cherry, Chemosphere, 1998, 36: 21 .

58 Zhang, Z. J., Bso, Z. C., Wang, K, O, et al. , The photolysis of chlorinated dibenzo-p-dioxin with titanium dioxide as cat- 
alyst, Environ. Chem. (in Chinese), 1996, 15: 47.

59 Vollmuth, S., Niessner, R., Degradation of PCDD, PCDF, PAH, PCB and chlorinated phenols during the destruction-treatment of landfill sewagewater in laboratory model reactor (UV, ozone, and UV/ozone), Chemosphere, 1995, $30: 2317$.

60 Smmer, S., Kamps, R., Kleinermanns, K., Photooxidation of exhaust pollutants: V Photooxidation and photoreduction of polychlorinated dibenzo-p-dioxins and dibenzofurans, Chemosphere, 1996,33: 2221.

61 Orazio, C. E., Kapilla, S., Puri, P. K., Persistence of chlorinated dioxins and furans in the soil environment, Chemosphere, 1992, 25: 1467.

62 Du, X. Y., Zhu, N. Q., Xia, X. J. et al. , A perliminary approach to biodegradation of polychlorinated dibenzo-p-dioxins (PCDDs), Environ. Chem. (in Chinese), 1995, 14: 187.

63 Adriaens, P., Gribic'-Galic, D., Reductive dechlorination of PCDD/F by anaerobic cultures and sediments, Chemosphere, $1994 ; 29: 2253$.

64 Disse, C., Weber, H. , Hamann, R. et al. , Comparison of PCDD and PCDF concentrations after aerobic and anaerobic digestion of sewage sludge, Chemosphere, 1995, 31: 3617 .

65 Hilarides, R. J., Gray, K. A., Guzzetta, J. et al., Feasibility system design and economic evaluation of radiolytic degradation of 2, 3, 7, 8-tetrachlorodibenzo-p-dioxin on soil, Water Environ. Res., 1996, 66: 178.

66 Oku, A., Tomari, K. , Kamada, T. et al ., Destruction of PCDDs and PCDFs: A convenient method using alkalimetal hydroxide in 1, 3-dimethyl-2-imidazolidinone (DMI), Chemosphere, 1995, 31 : 3873.

(Received September 11, 1998) 